\title{
JPCS
}

Peqguruang: Conference Series

Vol.2.No.2.Nov. 2020

elSSN: 2686-3472

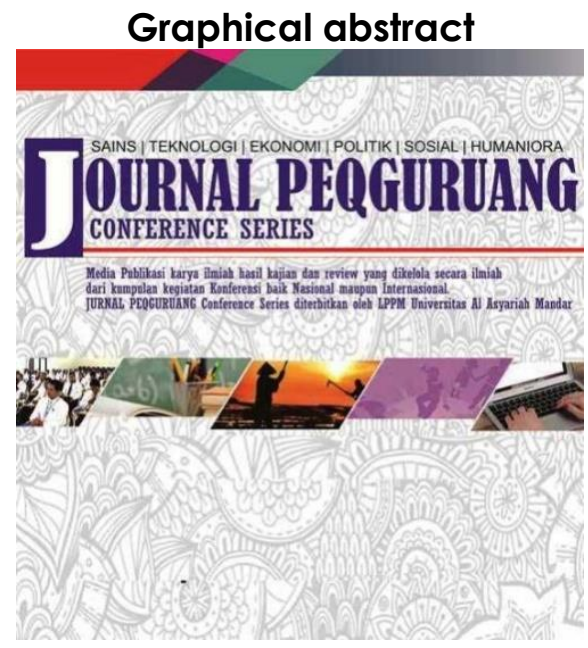

\section{PENINGKATAN KETERAMPILAN MENULIS PUISI MELALUI METODE NATURE LEARNING PADA PESERT DIDIK KELAS X SMK ARMIDA ABDULLADIN}

$1 *$ Rinaldi, ${ }^{*}$ Sulihin Azis,,${ }^{1 *}$ Abd. Azis

1Universitas Al Asyariah Mandar aldi59905@gmail.com

\begin{abstract}
This research is included in the type of classroom action research (CAR). This study aims to improve students' writing skills by using nature learning methods. Data collection techniques are tests, observations and interviews. This research instrument uses a test instrument that includes student worksheets and non-test instruments include student observation sheets and interviews. The data analysis technique used is descriptive statistical analysis. The results showed that this study was successful and was able to improve students' poetry writing skills through the nature learning method. Seen in the results of the first cycle the average value of students is 67.25 while in the second cycle the average score obtained by students is 80.95 . Thus it can be concluded that there is a significant increase in students' writing skills in aspects of poetry writing skills through the nature learning method.
\end{abstract}

Keywords: Writing, Poetry, Nature Learning.

\begin{abstract}
Abstrak
Penelitian ini termasuk dalam jenis penelitian tindakan kelas (PTK). Penelitian ini bertujuan untuk meningkatkan keterampilan menulis peserta didik dengan menggunakan metode nature learning. Tekhnik pengumpulan data yaitu tes, observasi dan wawancara. Instrumen penelitian ini menggunakan instrument tes yang mencakup lembar kerja peserta didik dan instrument non tes mencakup lembar observasi dan wawancara peserta didik. Adapun teknik analisis data yang digunakan adalah menggunakan analisis statistik deskriptif. Hasil penelitian menunjukkan bahwa penelitian ini berhasil dan mampu meningkatkan keterampilan menulis puisi peserta didik melakui metode nature learning. Terlihat pada hasil siklus I rata-rata nilai siswa adalah 67,25 sedangkan pada siklus II skor rata-rata yang diperoleh siswa adalah 80,95. Dengan demikian dapat disimpulkan bahwa terdapat peningkatan yang siginifikan pada keterampilan menulis peserta didik pada aspek keterampilan menulis puisi melalui metode natur learning.
\end{abstract}

Katakunci: Menulis, Puisi, NatureLearning.

\section{Article history}

DOI: http://dx.doi.org/10.35329/jp.v2i2.989

Received : 13 Agustus 2020 | Received in revised form : 3 September 2020 | Accepted : 9 Oktober 2020 


\section{PENDAHULUAN}

Kurikulum tingkat satuan pendidikan (KTSP) merupakan kurikulum yang disempurnakan oleh kurikulum 2013. Menurut ma'as shobirin , 2016;35 mengungkapkan kurikulum adalah seperangkat rencana yang mempunyai isi dan bahan pelajaran serta cara yang digunakan sebagai acuan penyelenggaraan untuk menggapai tujuan pendidikan tertentu.

Teks adalah materi yang memberikan ransangan kepada peserta didik dalam pembelajaran kurikulum 2013. Adapun teks yang menjadi salah satu pembelajaran dalam kurikulum 2013 pada peseta ditingkatan SMA/MA/SMK adalah teksmenulispuisi.Sebagai suatu keterampilan, menulis memang harus melalui proses belajar dan berlatih. Semakin sering belajar dan berlatih, tentu semakin cepat terampil. Seseorang yang sudah biasa menuliskan sebuah ide, gagasan, pendapat, atau perasaannya, maka dia tidak akan mengalami kesulitan berarti ketika harus menulis. Berbeda halnya jika seseorang jarang atau bahkan sama sekali tidak pernah membuat sebuah karya tulisan. Tentunya orang tersebut akan mengalami banyak kesulitan ketika diminta menuliskan sesuatu.

Selain itu kemampuan berpikir juga akan mempengaruhi kemampuan seseorang untuk menuliskan sesuatu, misalnya: karya ilmiah, cerita pendek, atau puisi. Kemampuan berpikir siswa sekolah dasar (SD) maupun siswa sekolah menengah pertama (SMP) akan berbeda dengan cara berpikir siswa sekolah menengah atas (SMA). Pada siswa SD maupun SMP kelas IX kemampuan berpikir mereka dapat dikatakan masih bersifat kekanak-kanakan dan kemampuan berpikir yang bersifat imajinatif belum berkembang dengan baik. Menurut Alfiah dan Yunarko Budi Santosa (2009:1), peningkatan pembelajaran menulis puisi kepada anak-anak yang masih berpikiran seperti itu sangatlah penting.

Lebih lanjut, dijelaskan bahwa dalam pembelajaran penulisan puisi untuk tingkatan SMA masih ada berbagai kelemahan. Kelemahan tersebut berakibat antara lain: siswa mengalami kesulitan dalam membuat puisi (baik puisi lama maupun puisi baru), nilai pelajaran yang berkaitan dengan puisi tidak memuaskan, tidak ada ketertarikan siswa dalam pelajaran bahasa Indonesia khususnya menulis puisi dan kurangnya pemahaman siswa dalam pembelajaran penulisan puisi.

Demikian pula yang terjadi pada siswa kelas X SMK Armida Abduladin Tahun Ajaran 2019-2020. Berdasarkan wawancara dengan guru kemampuan menulis puisi siswa X SMK Armida Abduladin Tahun ajaran 2019-2020 dinilai masih rendah. Hal itu dapat diketahui dari hasil belajar siswa pada mata pelajaran bahasa Indonesia. Jika dilihat dari KKM (Kriteria Kelulusan Minimal) yang ditetapkan oleh sekolah yaitu 70, maka baru $30 \%$ atau 6 siswa dari total 18 siswa kelas X SMK Armida Abduladin yang dinyatakan tuntas dalam pembelajaran menulis puisi sedangkan yang tidak tuntas sebanyak 12 siswa (65\%). Hal ini tentunya masih menunjukkan bahwa pembelajaran menulis, khususnya menulis puisi di kelas X SMK Armida Abduladin masih belum optimal.

Guru Bahasa Indonesia SMK Armida Abduladin mengatakan bahwa faktor utama penyebab masih rendahnya kemampuan menulis puisi pada siswa yaitu siswa masih mangalami kesulitan mendapatkan ide, dengan kata lain ide yang dimiliki oleh siswa belum berkembang dengan baik. Selain itu minimnya penggunaan metode dalam pembelajaran menulis puisi disinyalir juga menjadi salah satu faktor penyebab masih rendahnya kemampuan menulis puisi pada siswa.

Untuk meningkatkan proses pembelajaran siswa , maka dipandang perlu untuk mencari solusi dari permasalahan tersebut, metode pembelajaran yang dapat menjadi acuan dan dijadikan sebagai metode pembelajaran, salah satuya adalah metode yang berkaitan dengan alam yang mampu memunculkan gagasan supaya siswa giat giat mengikuti proses pengajaran di tempat pendidikan. kemunculan metode pada proses pengajaran mempunyai makna yang cukup berarti penting ketidakpastia pelajaran yang diutarakan oleh pemateri atau keinginan untuk menghadirkan gagasan baru dapat diperoleh dengan datangnya metode pembelajaran sebagai penengah. Cara untuk membangkitkan motifasi proses belajar peserta didik adalah dengan memakai metode, pemakaian metode dapat diklaim baik karena guru tidak hanya memakai metode ceramah saja dan tak membuat proses pembelajaran berjalan satu arah .

Sesuai proses pengamatan peneliti mengajukan solusi berupa penerapan metode, terkhusus nature learning yang merupakan pilihan peneliti dalam pengajaran menulis nulis puisi.Metode Nature learning sepertinya bagus dipakai pada pembelajaran puisi puisi karena cara ini merupakan cara yang gampang diketahui untuk cari cari gagasan apa' ini metode tidak membuat peserta didik tidak bosan belajar, apalagi mampu memberikan masukan masukan yang sehingga peserta didik mampu menuliskan segala hal.

Melalui metode pembelajaran nature learning diharapkan para siswa lebih giat untuk mengeksplorasi alam sekitar dan menjadikannya sebagai bahan referensi dalam penulisan puisi oleh siswa SMK Armida Abdulladin. Kelebihan dari metode ini adalah mampu mengajak siswa untuk berfkir secara terbuka dan mampu mengeksplorasi alam sekitar sebagai objek menulis puisi.

Sesuai dengan metode diatas, maka tujuan peneliti ini ialah "untuk meningkatkan keterampilan menulis puisi melalui metode nature learning pada peserta didik kelas X Smk armida abdulladin.

\section{Pengertian Menulis}

Menurut Dalman (2018: 3) mengemukakan bahwa menulis merupakan sebuah proses kreatif menuangkan gagasan dalam bentuk bahasa tulis dalam tujuan, misalnya memberitahu, meyakinkan, atau menghibur. Hasil dari proses kreatif ini bisa disebut 
dalam istilah karangan atau tulisan. Kedua istilah tersebut mengacu pada hasil yang sama meskipun ada pendapat yang mengatakan kedua istilah tersebut memiliki perngertian yang berbeda. Istilah menulis sering melekatkan pada proses kreatif yang sejenis ilmiah. Sementara istilah mengarang sering dilekatkan pada proses kreatif yang berjenis non-ilmiah.

Menurut Suparno dan Yunus (Dalman, 2018: 4) menulis merupakan suatu kegiatan penyampaian pesan (komunikasi) dengan menggunakan bahasa tulis sebagai alat atau metode nya. Selanjutnya, Tarigan (Dalman, 2018: 4) mengemukakan bahwa menulis ialah menurunkan atau melukiskan lambang-lambang grafis yang menghasilkan suatu bahasa yang pahami oleh seseorang sehingga orang lain dapat membaca lambanglambang grafis tersebut dan dapat memahami bahasa dan grafis itu.

Sejalan dengan pendapat di atas, Marwato (Dalman, 2018: 4) menjelaskan bahwa menulis adalah mengungkapkan ide atau gagasannya dalam bentuk karangan secara leluasa.Dalam hal ini, menulis itu membantu skemata yang luas sehinggan si penulis mampu menuangkan ide, gagasan, pendapatnya dengan mudah dan lancar.

Seseorang sepantasnya tertawa jika ada seseorang yang mengatakan bahwa dirinya tak mampu menulis. Hal ini sangat lucu, jika dikaitkan dengan pengertian keterampilan menulis yang dimaksudkan, bagimana seseorang dapat mengatakan tidak mampu menulis jika dia memang belum mempunyai keterampilan menulis. Semua orang harus paham tentang hal ini . jika menulis adalah sebuah keuletan yang berarti, semua manusia memiliki keterampilan dan mengasaha keterampilan lewat kesempatan. Maka salah satu cara yang dilakukan adalah dengan melatih diri, setiap orang dapat melatih diri dan mengikuti secara langsung pengertian keterampilan menulis selanjutnya menerapkan dalam kegiatan nyata.

Sesuai paparan di atas sana, bisa dirangkum kalau menulis ialah proses manusia mengungkapkan gagasan atau paradigma yang disalurkan kepada orang lain melalui ungkapan yang tak langsung, seperti gambar gambar, jadi manusia manusia lain paham kalau ada makna yang ada didalamnya.

Tujuan Menulis

Sehubungan dengan tujuan dalam menulis, maka Hugo Hartig (Kurniatama, 2016: 10-11) merangkumnya sebagai berikut:

a. Assigment purpose (tujuan penugasan)

Penulis menulis sesuatu karena ditugaskan, bukan karena maunya sendiri (contoh peserta didik yang dikasi tugas untuk menyimpulkan buku; sekertariss yang diberikan amanah untuk melaporkan hasil pertemuan).

b. Tujuan altruistik (Altruistic purpose)

Penulis menulis karena pembaca senang, menjauhkan duka lara penikmat, membantu penikmat mengetahui, menghormati rasa dan prasangka, mau menjadikan suasana pembaca lebih senang .

c. Persuasive purpose (tujuan persuasif)
Penulis menulis untuk membuat pembaca percaya terhadap keteapan idea tau nalar yang disalurkan.

d. tujuan informasional (Informational purpose)

Penulis menulis untuk memberi berita atau informasi /penerangan terhadap penikmat.

e. Self-expressive purpose (tujuan pernyataan diri)

Penulis menulis untuk mempromosikan diri atau pengungkapan pribadi penulis terhadap penikmat. Tahap-Tahap Menulis

Mencatat ialah proses, mencatat tidak hanya dilakukan melalui satu langkah. Sebagai sebuah pelajaran, mencatat terdiri dari kegiatan kegiatan yang bermula dari pengungkapan ide hingga sampai fase mengedit. Dalman (2018: 15-20), menjelaskan jika proses mencatat terbagi jadi 3 , yaitu ; persiapan ,pelaksanaan dan pasca penulisan.

a. Persiapan (Tahap Prapenulisan)

Fase ini adalah fase ke satu , fase kesiapan adalah fase yang mengharuskan pembelajar bersiap diri , menyatukan berita , mencantumkan masalah, merumuskan focus, memgelola berita , mencantumkan penafsiran kedalam kehidupan yang nyata, bercerita ,mengamati , membaca dan lain sebagainya untuk memperdalam pengetahuan kognitifnya yang akan diolah dikemudian hari.

1) Merumuskan topik

Topik ialah gagasan utama yang akan menjiwai sebuah tulisan. Topik beda sama tema . kalau tema bersifat umum sedangkan topik sifatnya khusus.

2) Tujuan dan sasaran yang tepat

Kerincian sebuah tulisan menjadi sesuatu yang harus diperhatikan agar sebuah tulisan tersampaikan secara benar . mempengaruhi adalah sasaran dan tujuan menulis.

3) Mengumpulkan Bahan dan Informasi Pendukung

Untuk menambah gaya menulis, dibutuhkan berita berita yang tidak melemahkan gairah agar tidak membuat tulisan jadi buruk, maka diusahakan harus ada pengetahuan yang luas supaya tulisan jadi bernilai di mata penikmat.

4) Mengorganisasikan Ide dan Informasi

Dalam menuangkan gagasan maka dipandang perlu bahwa sistem harus sesuai dengan urutan urutan dalam menulis agar gagasan yang diungkapkan mampu dicermati . pendahuluan, isi dan penutup adalah kerangka tulisan.

b. Proses Penulisan

Proses penulisan adalah proses menaruh agasan atau ide terhadap tulisan . pada proses ini, manusia membesarkan poin demi poin yang ada sebagaimana rangka menulis sesuatu dengan menggunakan berita yang disusun. Dalam membesarkan gagasan, penulis mesti menimbang agar isi tetap luas, macam macam berita yang harus tersaji dan mode model dalam bahasan.

c. Tahap Pasca Penulisan

Pada bagian ini mengungkapkan bagian bagian pengeditan agar sempurna sempurna sebuah karya. Bagian ini terbagi dua ,yaitu pengeditan dan 
pembaharuan . pengeditan ialah pengecekan poin poin karangan ,yaitu ; kepustakaan , diksi , ejaan dan sebagainya.

Perlakuan pengeditan bisa dikerjakan dengan

cara

a) Semua karangan dibaca

b) Menandai yang mau diganti

c) Memperbaiki masalah

Manfaat Menulis

Salah satu tokoh yang sering melakukan penelitian tentang pembelajaran

menulis yaitu Graves (Abdullah, 2017: 4-8) mengungkapkan bahwa manfaat menulis diantaranya yaitu:

\section{Menulis mengembangkan kecerdasan}

Para ahli psikolinguistik mengatkan bahwa menulis merupakan aktivitas kompleks yang terletak pada tuntunan kemampuan mengharmoniskan berbagai aspek, seperti pengetahuan tentang topik yang ditulis, kebiasaan menata isi tulisan secara runtut dan mudah dicerna, wawasan dan keterampilan meracik unsurunsur bahasa sehingga tulisan menjadi mudah dibaca, dan kesanggupan menyajikan tulisan yang sesuai dengan kaidah penulisan. Untuk menjadi penulis yang seperti itu, maka seorang penulis memerlukan kemampuan:

1) mendengar, melihat, dan membaca yang baik;

2) memilah, memilih, mengolah, mengorganisasikan secara kritis sistematis;

3) menganalisis sebuah persoalan dan berbagai perspektif;

4) memprediksi karakter dan kemampuan pembaca; dan

5) menata tulisan secara logis, runtut, dan mudah dipahami.

Tumbuh-kembangnya kemampun tersebut sekaligus mengasah kecerdasan dan daya pikir seseorang yang mau belajar menulis.

2. Pengembangan kekuatan kreativitas dan inisiatif

Jika ingin menjadi penulis yang baik, maka penulis tentu mempunyai kreativitas dan inisiatif yang tidak rendah dengan terus menggali bahan berita dari segala arah.

Penulis harus mengamati data yang akan dikelola dan seorang penulis menulis dan merangkai kata agar para penikmat langsung memahami bacaan yang ditulis.

3. Menulis menumbuhkan kepercayaan diri dan keberanian

Seoramg penulis haruslah berani dalam mengambil resiko agar tulisannya tetap eksis . perasaan takut tidak boleh melekat dalam diri , karena perasaan takut, cemas dan lain lain adalah salah satu jalkan yang akan membuat proses menulis seseorang akan terhambat .

olehnya itu, seorang penulis mesti mempunyai rasa siap dan sanggup untuk mengamati dengan teliti masukan dari orang lain , baik itu bersifar positif atau negatif.

4. Terbiasa menemukan berita akan meginspirasi kemauan menulis

Proses penyerapan sangat dibutuhkan dalam menulis , karena segala sesuatu akan diserap oleh penulis . contoh melalui berita radio, artikel ,nuku dan lain sebagainya.

Puisi

Puisi berasal dari kata poema yang berarti mencipta, to mace to creaty tak jauh beda maknanya sama poem ,sehingga dulu puisi pernah dinamakan maker di inggris sana (Di ,2017:9)

Puisi dikatakan sebagai pembangun, pembuat karena sebenarnya puisi ialah berasal dari kata kosep membangun .

Puisi ialah salah satu cabang sastra dengan menggunakan kata-kata sebagai media penyampaiannya yang disertai dengan pengembangan imajinasi dan estetika yang ada di dalamnya (Mudlofar dalam Iswahyuni, 2018: 22).Puisi merupakan karya seni yang multidimensi.Segala aspek kehidupan dapat dituangkan dalam bentuk puisi. Puisi bukan hanya sekedar ekspresi emosi dalam bentuk bunyi dan ritme (irama) saja akan tetapi sudah menjadi karya seni bahasa untuk menuangkan suatu ide atau gagasan mengenai pengalaman penulis.

Puisi adalah bentuk karangan yang bahasanya terikat oleh rima, irama, mantra, larik dan bait.Tiap puisi ditulis dalam bait-bait, setiap bait terdiri dari larik atau baris dan tiap baris mempunyai rima.Karangan ini berbicara lewat metafora, memberikan imaji-imaji yang sugestif, merangsang asosiasi-asosiasi dan menghadirkan suasana khas pada batin pembacanya (Dagun dalam Iswahyuni, 2018: 22).

Macam-Macam Puisi

Adapun macam-macam puisi menurut Purwandari (2015: 165) yaitu sebagai berikut:

Puisi Lama

Puisi lama ialah puisi yang mengalami perkembangan hingga zaman sekarang. Puisi lama sangat terikat oleh aturan seperti jumlah kata dalam satu baris, jumlah baris dalam satu bait, persajakan (rima), banyak suku kata tiap baris, dan irama. Ciri-ciri puisi lama yaitu: 1) merupakan puisi rakyat yang tidak dikenal nama pengarangnya; 2) disampaikan lewat mulut ke mulut, jadi dapat dikatakan sebagai sastra lisan; 3) sangat terikat oleh aturan-aturan seperti jumlah kata dalam satu baris, jumlah baris dalam satu bait, persajakan (rima), banyak suku kata tiap baris, dan irama.

Puisi Baru

Yang bentuknya bebas adalah puisi baru yang dilihat dari segi suku kata , baris, maupun rima.

Puisi Kontemporer

Puisi yang bentuknya bebas dan selalu ingin keluar dari ikatan atau kaidah adalah puisi kontemporer . kontemporer puisi selalu menggunakan kata kata yang tak sopan, selalu memguunakan kata kata kasar dan lain lain. 
Unsur-Unsur Puisi

Dalam puisi ada beberapa unsur yang perlu diperhatikan antara lain, saling berkaitan satu sama lain, saling menopang, dan tidak terpisahkan. Pada tulisan dapat dilihat dua unsur pembagun agar dapat dikatakan sebagai karya sastra, diantaranya;

a. Unsur Intrinsik Puisi (unsur pembagun dari luar puisi)

1) Tema

Tema adalah gagasan utama pembagun dari sebuah karya sastra yang menjadi dasar terciptanya sebuah karya sastra itu sendiri. Pada puisi dapa dilihat dari dua cara diantaranya; dengan melihat judul puisi dan melihat bentuk fiksi puisi.

2) Amanat

Amanat merupakan pesan yang di sampaikan oleh penulis dalam sebuah karyanya untuk ditujukan kepada pembaca.

3) Sifat, keadaan atau karakter.

Dalam membaca puisi tentu saja bukan hanya keindahan dalam penulisan, namun proses pembacaannya juga termasuk kedalam penilaain seperti saat membaca puisi akan terlihat menarik ketika pembacanya menjiwai puisi itu.

4) Tipografi

Tipografi adalah pada dasarnya disebut dengan wajah dari sebuah karya sastra, dapat dilihat dari atas kebawa. Tipografi biasanya dapat dilihat dari puisi modern saat ini maupun puisi kontenporer

5) Enjabemen

Enjambemen adalah pemindahan bagian kalimat pada larik berikutnya sehingga menimbulkan nuansa makna. Fungsi dari enjabemen ialah memperkuat antara makna dan larik pada sebuah karya sastra.

6) Rima atau Persamaan Bunyi

Rima adalah pengulangan kata yang memiliki bunyi yang teratur dan memiliki tempo yang teratur.

7) Citraan atau pengimajian

Citraan atau Pengimajian adalah proses penyajian karya sastra yang telah ditulis oleh sesorang dan siap untuk dijadikan sebagai pedoman dalam kegiatan. Pada citraan atau pengimijinasian ada beberapa yang perlu diperhatikan yaitu; (1) penglihatan, (2) pendengaran, (3) penciuman, dan (4) perasaan.

8) irama

Irama merupakan pengulangan kata terhadap ebuah kalimat dan memiliki keindahan dalam tulisan agar dapat tertarik dilihat atau di baca.

b. Unsur Ekstrinsik Puisi

Unsur ekstrinsik merupakan salah satu pembanguan dari puisi, dalam unsur ini ada beberapa komponen yang mesti kita perhatikan, diantaranya;

1) sense ialah sesuatu yang digambarkan atau diciptakan oleh penyair lewat puisi yang dibuatnya;

2) subject matter ialah pokok pikiran yang dikemukakan penyair lewat puisi yang diciptakannya;
3) feeling ialah sikap penyair terhadap pokok pikiran yang ditampilkannya;

4) tone ialah sikap penyair terhadap pembaca sejalan dengan pokok pikiran yang ditampilkan;

5) total of meaning ialah keseluruhan makna yang terdapat dalam suatu puisi;

6) theme ialah ide dasar suatu puisi yang menjadi keseluruhan makna puisi (Iswahyuni, 2018: 27-29).

Ciri-Ciri Puisi

a. bentuk bait yang terdiri atas baris-baris, bukan bentuk paragraf seperti pada prosa dan dialog seperti pada naskah drama.

b. Diksi yang bersifat kias, padat, dan indah.

c. Majas menjadi dominan dalam bahasa puisi dengan mempertimbangkan rima dan persajakan.

d. Cenderung menunjukkan Setting, alur, dan tokoh.

Langkah-Langkah Pembelajaran Keterampilan Menulis Puisi

Murdiana (2017: 30-32) menjelaskannya sebagai berikut :

a. Penentuan Tema

Tema puisi ialah pokok permasalahan dalam puisi yang secara keseluruhan di ungkapkan oleh pengarang. Tema puisi bisa juga disebut sebagai dasar cerita atau titik tolak pengarang dalam menyusun suatu posisi

b. Bentuk dan struktur puisi

Bentuk dan struktur puisi dapat mengintensifkan makna puisi yang ingin di ungkapkan pengarang

c. Pilihan kata/diksi

Kata-kata selain mengandung nilai, ia juga mempunyai makna yang mendalam. Untuk itulah dalam sebuah puisi dibutuhkan pemillihan diksi yang tepat.

d. Penggunaan manijasi dalam penyajian

Segala sesuatu yang yang pernah menyentu perasaan anda, singgah dan tersimpan dalam pikiran anda, ungkapkan dalam fikiran anda ungkapkan dalam bentuk pilihan kata yang tepat itulah yang dibutuhkan dalam puisi.

e. Gaya bahasa atau majas

Penggunaan daya imajinasi yang baik, membuat pembaca puisi seperti merasakan sendiri apa yang diungkapkan penyair, penggunaan gaya bahasa atau majas seperti:

Hiperbola, gaya bahasa berlebihan

Contoh: Senyummu membekas menggerogoti tubuhku.

Metafora, perbandingan sesuatu dengan sesuatu lain.

Contoh: Pemuda adalah tiang negeri ini.

Personifikasi, penggambaran benda mati seperti halnya manusia

Contoh: kau seperti melati tumbuh didalam hati

Pararelisme :pengulangan isi kalimat dengan kalimat lain yang sama

Contoh:lluasnya samudra telah kujarungi timgginya gunung telah kudaki 
Enumerasi: memberikan intensitas dengan memerinci masalah contoh,:dalam suka, dalam duka bahkan aku kecewa padamu aku tetap setia

f. Evaluasi

Guru mengevaluasi siswa agar mengetahui sejauh mana pemahaman mereka setelah melakukan proses pembelajaran.

\section{g. Penghargaan}

Bentuk verbal maupun nonverbal dapat diberi penghargaan dengan cara sementara dan setelah pembelajaran selesai. Skor tertinggi akan mendapat penghargaan dari guru. Tetapi semua siswa atau tim sebaiknya diberi penghargaan yang berbeda-beda sesuai kemampuan mereka dalam mencapai standar tertentu yang telah ditentukan sebelumnya.

h. Penutup

Guru dan peserta didik merangkum, merefleksi, dan menutup pembelajaran.

Metode Nature Learning.

Metode pembelajaran dengan menjadikan alam sekitar sebagai media disebut sebagai Metode Nature Learning. Melibatkan siswa untuk terlibat langsung dan beraktivitas dengan alam bebas agar dapat menumbuhkan semangat menulis dan juga menumbuhkan kreatifitas dan produktivitas dalam menulis puisi (septiana dwi lestari ,2012:3).

Metode nature learning sebagai alat untuk merubah pola fikir siswa dalam proses pembelajaran, adapun langkah langkah dalam menerapkan metode nature learningadalah sebagai berikut:

1. Peneliti yang hendak menggunakan metode nature learningbaiknya memahami materi materi yang akan menjadi unsur pembangun dalam puisi.

2. Dari seluruh komponen pembangun puisi termasuk pemilihan diksi hendaknya lebih diutamakan dalam penulisan puisi.

3. Pada peneletian ini menggunakan alam bebas sebagai media agar para peserta didik mampu mengeksplorasi keadaan sekitar agar mampu menghasilkan diksi diksi yang baik.

Metode nature learning dimaksudkan agar para peserta didik mampu menghasilkan karya yang dapat merubah pola fikir peserta didik agar tidak merasakan kejenuhan ketika belajar didalam kelas. metodeinimempunyaikelebihandankekurangan adapunkelebihandankekurangannyaadalahsebagaiberik ut :

\section{1) KelebihanMetodeNature Learning}

Metode nature learning merupakan metode efektif dalam pengembangan menulis puisi, karena metode ini merupakan metode yang bersentuhan langsung dengan keadaan alam ,adapun kelebihan dari metode ini adalah sebagai berikut:

a. Metode nature learning memberi peluang kepada peserta didik agarmampu menciptakan puisi puisi yang baik.

b. Metode ini mencoba memberikan kesenangan terhadap siswa dalam mengikuti kegiatan pembelajaran agar tidak menemui kejenuhan didalam kelas.

2) Kekurangan Metode NatureLearning

Disamping adanya kelebihan,metode ini juga mempunyai kekurangan. Adapun kekurangannya adalah sebagai berikut :

a. Metode nature learning ini cenderung dianggap sebagai metode yang tidak efektif sebab metode ini berinteraksi langsung dengan alam sekitar.

b. Metode nature learning ini terkadang tidak efektif bagi peserta didik karena adanya kebebasan peserta berinteraksi dengan dunia luar.

\section{METODE PENELITIAN}

Jenis penelitian yang digunakan pada penelitian ini adalah Penelitian Tindakan Kelas (classroom action research). Hasil belajar bahasa Indonesia dikhususkan pada keterampilan menulis puisi. Dikatakan penelitian tindakan kelas (PTK) karena setting berada di dalam kelas dan objek yang diteliti berupa praktik pembelajaran. PTK dilaksanakan dalam wujud proses pengkajian berdaur yang terdiri atas empat tahap, yakni perencanaan, pelaksanaan tindakan, observasi (pengamatan), dan refleksi (Sanjaya, 2017: 20). Tempat dan Waktu Penelitian

Penelitian ini dilaksanakan di kelas X SMK Armida Abduladin.Waktu penelitian ini di mulai pada semester genap bulan Februari sampai April tahun 2020.

Desain penelitian

Arikunto (2009: 3) menjelaskan bahwa Penelitian Tindakan Kelas adalah suatu perencanaan terhadap kegiatan belajar berupa sebuah tindakan yang sengaja dimunculkan dan terjadi dalam sebuah kelas secara bersama. Tahapan dalam tindakan kelas ini meliputi perencanaan, pelaksanaan, observasi, dan refleksi.

Desain Penelitian Tindakan Kelas, Arikunto (2013: 3)

Dalam penelitian ini dilakukan dalam dua siklus sebagai berikut,penelitian ini terdapat siklus I dan siklus N.

1. Siklus I

Dalam siklus ini peneliti merencanakan program sebagai berikut:

a. Perencanaan

1) Menelaah materi pelajaran bahasa Indonesia.

2) Menentukan materi yang akan diajarkan.

3) Membuat RPP dengan langkah-langkah sesuai dengan metode nature learning.

4) Membuat pedoman observasi.

5) Membuat dan menyusun alat evaluasi.

b. Pelaksanaan Tindakan

Pelaksanaan tindakan ialah:

1) Pembukaan pelajaran oleh guru seerta menanyakan kesiapan siswa untuk menerima pelajaran. 
2) Guru menginformasikan kompetensi yang harus dicapai dalam pembelajarannya.

3) Memberikan motivasi dan pertanyaan terbuka tentang puisi dengan tema lingkungan sekolah.

4) Guru menjelaskan tentang garis besar cakupan materi.

5) Guru mengajak siswa keluar kelas untuk menerapkan metode nature learning.

6) Membagi siswa dalam kelompok belajar yang terdiri dari 4-5 siswa.

7) Guru memberi kesempatan kepada siswa untuk mengindentifikasi permasalahan atau fenomenafenomena yang terjadi dalam kehidupan sehari-hari (khususnya yang akan menjadi objek puisi ditulis).

8) Memberi waktu dan kesempatan kepada siswa untuk mengungkapkan gagasannya dan juga membimbing siswa untuk menyepakati yang akan menjadi objek puisi yang berkaitan tentang kehidupan sehari-hari.

9) Setelah itu, guru memberikan waktu untuk menulis sebuah puisi berdasarkan fenomena yang telah dipilih.

\section{c. Observasi}

Observasi ini dilakukan pada saat proses belajar mengajar sedang berlangsung. Aspek-aspek yang diobservasi adalah sebagai berikut:

1) Keaktifan siswa selama proses pembelajaran berlangsung.

2) Keseriusan siswa selama proses pembelajaran berlangsung.

3) Perhatian siswa terhadap materi pelajaran.

4) Sikap jujur siswa dalam mengerjakan tugas.

5) Tes tertulis untuk mengetahui tingkat pemahaman siswa terhadap materi pelajaran.

d. Refleksi

Perhitungan hasil yang didapat pada tahap observasi dan evaluasi dikumpulkan dan dianalisis pada tahap ini. Hal-hal yang masih dianggap kurang kemudian diperbaiki dan dikembangkan ulang.

2. Siklus II

a. Perencanaan

1) Menelaah materi pelajaran bahasa Indonesia.

2) Menentukan materi yang akan diajarkan.

3) Membuat RPP dengan langkah-langkah sesuai dengan metode nature learning

4) Membuat pedoman observasi.

5) Membuat dan menyusun alat evaluasi.

b. Pelaksanaan Tindakan

1) Pembukaan pelajaran oleh guru serta menanyakan kesiapan siswa untuk menerima pelajaran

2) Guru menginformasikan kompetensi yang harus dicapai dalam pembelajarannya,

3) Memberikan motivasi dan pertanyaan terbuka tentang puisi dengan tema bebas.

4) Guru menjelaskan tentang garis besar cakupan materi.
5) Membagi siswa dalam kelompok belajar yang terdiri dari 4-5 siswa.

6) Guru memberi kesempatan kepada siswa untuk mengindentifikasi permasalahan atau fenomenafenomena yang terjadi dalam kehidupan sehari-hari (khususnya yang akan menjadi objek puisi ditulis).

7) Guru memberi waktu dan kesempatan kepada siswa untuk mengungkapkan gagasannya dan juga membimbing siswa untuk menyepakati yang akan menjadi objek puisi yang berkaitan tentang kehidupan sehari-hari.

8) Setelah itu, guru memberikan waktu untuk menulis sebuah puisi.

c. Observasi

Observasi ini dilakukan pada saat proses belajar mengajar sedang berlangsung. Aspek-aspek yang diobservasi adalah sebagai berikut:

1) Keaktifan siswa selama proses pembelajaran berlangsung.

2) Keseriusan siswa selama proses pembelajaran berlangsung.

3) Perhatian siswa terhadap materi pelajaran.

4) Sikap jujur siswa dalam mengerjakan tugas.

5) Tes tertulis untuk mengetahui tingkat pemahaman siswa terhadap materi pelajaran.

d. Refleksi

Perhitungan hasil yang didapat pada tahap observasi dan evaluasi dikumpulkan dan dianalisis pada tahap ini. Hal-hal yang masih dianggap kurang kemudian diperbaiki dan dikembangkan ulang.

Subjek penelitian adalah siswa kelas X SMK Armida Abduladin Kabupaten Majene yang berjumlah 14 orang diantaranya terdapat 8 perempuan dan 6 laki laki pada tahun ajaran 2019-2020 .

Instrumen Penelitian yang digunakan adalah instrument tes dan non tes.

Instrumen Tes

Menurut Sanjaya (2015: 99), tes memiliki tingkat validitas ketika dapat mengukur apa yang hendak diukur. Tes juga merupakan pertanyaan yang diberikan pada siswa sebagai umpan balik dalam memahami materi.Tes tersebut digunakan untuk melihat tingkat keberhasilan tindakan yang dilakukan.

Instrumen tes digunakan untuk mengungkapkan data keterampilan menulis puisi dengan menggunakan metode nature learning:Instrumen yang diberikan berupa perintah kepada siswa untuk melakukan kegiatan menulis puisi dan setelah siswa selesai menerima materi, siswa langsung diperintahkan mengerjakan soal menulis puisi. Dikatakan mencapai kategori kurang jika nilai antara 34-56, kategori cukup jika siswa mendapat nilai antara 57-69, jika kategori baik siswa mendapat nilai antara 7089, dan kategori sangat baik siswa mendapat nilai antara 90-100.

Instrumen Nontes 
Untuk mengetahui perubahan perilaku dan sikap siswa dalam pembelajaran dan tanggapan siswa mengenai pembelajaran yang telah dilakukan selama mengikuti pembelajaran menulis puisi dengan menggunakan metode nature learning.Bentuk instrumen nontes dalam penelitian ini yaitu pedoman observasi dan pedoman wawancara.

Pedoman Observasi

digunakan untuk mengamati keadaan dan sikap siswa yang terjadi selama pembelajaran pada setiap siklus. diantaranya (1) kehidaran siswa saat proses pembelajaran berlangsung, (2) Siswa yang mengangkat tangan dengan maksud ingin bertanya kepada guru, (3) Siswa yang menjawab pertanyaan dari guru, (4) Siswa yang mengangkat tangan memberikan tanggapan atau komentar kepada teman, (5) Siswa yang aktif diskusi, (6) Siswa yang suka keluar kelas ketika proses belajar berlangsung., (7) Siswa yang menyampaikan tugasnya di depan kelas, dan (8) keseriusan siswa dalam mengerjakan soal.

Pedoman Wawancara

Untuk mendapatkan informasi tentang keadaan responden dengan tanya jawab dan diskusi dengan siswa tentang variabel penelitian. Aspek yang digunakan untuk pedoman wawancara antara lain, 1) Bagaimana pendapat kalian mengenai pembelajaran menulis puisi dengan menggunakan metode nature learning? 2) Apakah kalian benar-benar memahami penjelasan guru dalam pembelajaran menulis puisi dengan menggunakan metode nature learning 3) Apa hambatan yang kalian hadapi selama pembelajaran? 4) Apa penyebab hambatan yang kalian rasakan dalam pembelajaran? 5) Berikan pendapat kalian mengenai pembelajaran menulis puisi dengan menggunakan metode nature learning?.

Tehnik analisis data

Adapun teknik analisis data yang digunakan adalah menggunakan analisi statistik deskriptif. Data yang diperoleh dalam teknik ini seperti: mean, modus, range, minimum, maximum.

Adapun proses statistik deskriptif secara manualnya adalah dengan rumus :

Rata-rata (mean)

Rata-rata adalah jumlah dari seraingkaian data dibagi dengan jumlah data. Rumusnya adalah :

$$
\begin{aligned}
& \qquad \bar{x}=\frac{\sum x_{i}}{n} \\
& \text { Keterangan: } \\
& \sum \mathrm{X}_{\mathrm{i}}=\text { Nilai tiap data } \\
& X \quad=\text { rata-rata } \\
& N=\text { jumlah data }
\end{aligned}
$$

Median (Me)

Skor/nilai data yang terletak ditengah setelah data disusun dari kecil ke besar (atau sebaliknya).

$M e=b+p\left(\begin{array}{c}\frac{1}{2} n-F \\ f\end{array}\right)$

Keterangan:

$\mathrm{b}=$ Batas bawah kelas median, ialah dimana media terletak

$\mathrm{p}=$ Panjang kelas median $\mathrm{n}=$ Ukuran sampel atau banyaknya data

$\mathrm{F}$ = Jumlah semua frekuensi dengan tanda kelas lebih kecil daripada sebelum frekuensi kelas median.

$\mathrm{f}=$ Frekuensi kelas median.

1. Modus (Mo)

Modus adalah skor/nilai yang paling banyak muncul/terjadi.

Mo $=\mathrm{b}+\mathrm{p}\left(\frac{b 1}{b 1+b 2}\right)$

Keterangan :

$\mathrm{b}=$ Batas bawah kelas modus, ialah kelas interval dengan frekuensi terbesar

$\mathrm{p}=$ Panjang kelas modus

$b_{1}=$ Frekuensi kelas modus - frekuensi kelas interval dengan tanda kelas yang lebih kecil sebelum tanda kelas modus.

$b_{2}=$ Frekuensi kelas modus - frekuensi kelas interval dengan tanda kelas yang lebih besar sesudah tanda kelas modus

\section{HASIL PENELITIAN DAN PEMBAHASAN}

Jumlah peserta didik pada penelitian ini sejumlah 14 orang , pada bagian ini peneliti akan mengemukakan hasil akhir dari penelitian secara siginifikan agar para peneliti selanjutnya mampu lebih memahami secara mendalam tentang penelitian berbasis PTK. Pada bagian ini hasil siklus I mencapai rata rata 67.25 dengan nilai minimum sejumlah 58.33 dan nilai maksimun mencapai 79.16 , sedangkan pada siklus II mencapai nilai rata rata 80.95 dengan nilai minimun sejumlah 62.50 dan nilai maksimun sejumlah 95.83 . Dengan demikian dapat disimpulkan bahwa peserta didik kelas X SMK Armida abdulladin mampu menulis puisi melalui metode nature learning .

Hasil observasi peserta didik pada siklus I dan II menunjukkan hasil yang berbeda .Hasil siklus I menunjukkan bahwa aktifitas tidak relevan menunjukkan bahwa masih terdapat aktifitas yang tidak relevan dilakukan oleh peserta didik, sedangkan pada siklus II menunjukkan bahwa aktifitas relevan lebih dominan dilakukan oleh peserta didik .

Pada bagian observasi guru siklus I dan II menunjukkan hasil yang berbeda, sebab pada bagian siklus II juga mengalami perubahan dikarenakan pada siklus II aktifitas guru sudah mulai terlaksana dengan baik . Pada siklus I aktifitas guru yang terlaksan adalah $30 \%$ dengan persentase $100 \%$, sedangkan pada siklus II aktifitas guru yang terlaksana sejumlah $60 \%$.

Pada bagian Wawancara mengenai respon peserta didik dalam mengikuti pembelajaran menulis puisi juga menunjukkan hasil yang baik dikarenakan respon peserta didik lebih menunjukkan respon positif dari lima pertanyaan yang dikemukakan oleh peneliti.

\section{Pembahasan}

Analisis deskriptif hasil belajar bahasa Indonesia peserta didik kelas X SMK Armida abdulladin yang telah diuraikan pada hasil penelitian menunjukkan bahwa pada tes siklus I jumlah skor rata rata yang 
diperoleh siswa yaitu , 67.25 sedangkan pada siklus II skor perolehan rata rata yang diperoleh peserta didik yaitu , 80.95 . Hal ini dapat disimpulkan bahwa penelitian ini terjadi peningkatan yang signifikan pada peserta didik dalam meningkatkan keterampilan menulis puisi melalui metpde nature learning.

Pada table berikut, dijelaskan bahwa rincian ketuntasan antara siklus I dan II pada pembelajaran menulis puisi yang dilaksanakan di kelas X SMK Armida Abdulladin.

Table 4.21 distribusi frekuensi ketuntasan tiap siklus

\begin{tabular}{|c|c|c|c|c|c|}
\hline \multirow{2}{*}{ No } & \multirow{2}{*}{ Nilai } & \multicolumn{2}{|c|}{ Frekuensi } & \multicolumn{2}{c|}{ Persentase\% } \\
\cline { 3 - 6 } & & $\begin{array}{c}\text { Siklus } \\
\text { I }\end{array}$ & $\begin{array}{c}\text { Siklus } \\
\text { II }\end{array}$ & $\begin{array}{c}\text { Siklus } \\
\text { I }\end{array}$ & $\begin{array}{c}\text { Siklus } \\
\text { II }\end{array}$ \\
\hline 1 & $0^{-} 74$ & 10 & 2 & 71.4 & 14.7 \\
\hline 2 & $75^{-} 100$ & 4 & 12 & 28.6 & 85.3 \\
\hline
\end{tabular}

Sumber data: Hasil analisis terhadap hasil lembar kerja peserta didik kelas X Smk Armada Abdulladin

Pada tabel 4.21 diatas terlihat adanya peningkatan yang signifikan antara siklus I dan II . Pada siklus I nilai rata rata yang diperoleh siswa yaitu ,67.25 dan pada siklus II nilai rata rata yang diperoleh oleh siswa adalah 80.95 .

\section{SIMPULAN}

Berdasarkan hasil diatas dapat dikemukakan bahwa pembelajaran keterampilan menulis puisi melalui metode nature learning mampu meningkatkan hasil belajar siswa secara efektif yang sesuai dengan tujuan pembelajaran. Hal ini dapat dilihat pada siklus perbedaan yang signifikan antara siklus I dan siklus II.

\section{DAFTAR PUSTAKA}

Abdullah, Asep Abbas. et.all. 2017.Teknik Penulisan karya IImiah. Surabaya: UIN Sunan Ampel Pers. Chaer, abdul . 2015 .filsafat bahasa .Jakarta .Rineka jaya.

Dalman. 2018. Keterampilan Menulis. Jakarta: Raja Grafindo Persada.

Dwi, Gina Febriyani. 2017. Pembelajaran Menulis Kreatif Puisi Dengan Menggunakan Media Diorama Pada Siswa Kelas VIII MTs Nurul Falah Cimahi Tahun

Pelajaran2016/2017.(online),(http://repository.unpas.a c.id /15678/5/BAB\%20II.pdf, Diakse 24 Desember 2018)

Nurgiyantoro, Burhan. 2001 Penelitian Dalam Pengajaran Bahasa Dan Sastra. Yokyakarta: BPPE Samosir, Tiorida. 2013. Apresiasi Puisi. Bandung: Yrama Widya.
Yunus ,nur hafsah , s. a. (2019). korelasi antara penggunaan media gambar dalam menulis puisi terhadap hasil belajar peserta didik kelas VII smp negeri satu atap luyo. universitas al asyariah mandar: jurnal peqguruang.

Azis, S., \& Andriani, A. (2021). ANALISIS STRUKTURAL DALAM CERITA RAKYAT MANDAR MELALUI PENDEKATAN ROBERT STANTON. LINGUISTIK: Jurnal Bahasa dan Sastra, 5(2), 362-371.

Azis, S. (2016). Peningkatan kemampuan menulis puisi dengan menggunakan teknik akrostik pada peserta didik kelas viii b smp negeri 1 wonomulyo kec. wonomulyo kab. polewali mandar. Pepatudzu: Media Pendidikan dan Sosial Kemasyarakatan, 10(1), 68-84.

Yunus, N. H., Azis, S., \& Andriani, A. (2020). FUNGSI BAHASA REGISTER PADA ANGGOTA KEPOLISIAN. LINGUISTIK: Jurnal Bahasa dan Sastra, 5(1), 170-178.

Azis, A. S. (2017). TINJAUAN HUKUM ISLAM TERHADAP BURUH PATTEI ANJORO (STUDI KASUS DESA LEKOPA'DIS KECAMATAN TINAMBUNG KABUPATEN POLEWALI MANDAR). J-Alif: Jurnal Penelitian Hukum Ekonomi Syariah dan Budaya Islam, 2(2), 1-17. 